\title{
Production of Functional Killer Protein in Batch Cultures Upon a Shift from Aerobic to Anaerobic Conditions
}

\author{
Gildo Almeida da Silva ${ }^{1 *}$, Jandora Severo Poli ${ }^{2}$, Carolina Madalozzo Poletto ${ }^{2}$, Patricia \\ Dayane Carvalho Schaker ${ }^{2}$ and Patricia Valente ${ }^{3}$ \\ ${ }^{I}$ Departamento de Microbiologia; Empresa Brasileira de Pesquisa Agropecuária; Centro Nacional de Pesquisa de \\ Uva e Vinho; 95700-000; Bento Gonçalves - RS - Brasil. ${ }^{2}$ Empresa Brasileira de Pesquisa Agropecuária; Centro \\ Nacional de Pesquisa de Uva e Vinho; 95700-000, Bento Gonçalves - RS - Brasil. ${ }^{3}$ Universidade Federal do Rio \\ Grande do Sul; Departamento de Microbiologia; Porto Alegre - RS - Brasil
}

\begin{abstract}
The aim of this work was to study the production of functional protein in yeast culture. The cells of Saccharomyces cerevisiae Embrapa $1 B\left(K^{+} R^{+}\right)$killed a strain of Saccharomyces cerevisiae Embrapa $26 B\left(K R^{-}\right)$in grape must and $Y E P D$ media. The lethal effect of toxin-containing supernatant and the effect of aeration upon functional killer production and the correlation between the products of anaerobic metabolism and the functional toxin formation were evaluated. The results showed that at low sugar concentration, the toxin of the killer strain of Sacch. cerevisiae was only produced under anaerobic conditions. The system of killer protein production showed to be regulated by Pasteur and Crabtree effects. As soon as the ethanol was formed, the functional killer toxin was produced. The synthesis of the active killer toxin seemed to be somewhat associated with the switch to fermentation process and with concomitant alcohol dehydrogenase $(A D H)$ activity.
\end{abstract}

Key words: Killer yeast, Crabtree effect, Pasteur effect, inhibition, mycocinogenic strain

\section{INTRODUCTION}

The killer phenomenon is determined by a low molecular weight protein excreted by yeast strains. These yeasts secret glycoprotein toxins that kill the sensitive strains in grape must and YEPD media (da Silva, 1996) and in many other culture media. Killer yeasts are present in grapes of several Brazilian vineyards (da Silva, 1999) and in many wine regions all over the world (Heard and Fleet, 1987; Vagnoli et al., 1993; Vazquez and Toro, 1994; Hidalgo and Flores, 1994; Cansado et al., 1999; Gutiérrez et al., 2001; Yap et al., 2000; Sangorrin et al., 2001; Sangorrin et al., 2007; Kapsopoulou et al., 2008). They have been reported in many other habitats as well (Musmanno et al., 1999; Ceccato-Antonini et al., 2004; Zarowska et al., 2004; Cabral et al., 2008). Killer yeasts are normally used in wineries. Attempts also have been made to use the killer yeasts in other industrial processes (Bajaj and Sharma, 2010). It has been observed that growing Sacch. cerevisiae treated with the toxins showed several cellular disorders, such as leakage of potassium, partial dissipation of the ATP pool, and alteration of macromolecular synthesis (Bussey and Skipper, 1975).

The Sacch. cerevisiae K28 toxin acts differently. This kind of toxin enters the susceptible cells by endocytosis, travels the secretion pathway in

*Author for correspondence: gildo@ cnpuv.embrapa.br 
reverse, and induces a cell cycle arrest at the G1/S boundary (Schmitt et al., 1996; Eisfeld et al., 2000). The outcome of these processes is the eventual death of the cells. The heterodimeric toxin is processed by a precursor in the Golgi apparatus (Bostian et al., 1984; Boone, 1986; Bussey, 1991; Cooper and Bussey, 1992). A carboxypeptidase is involved in the processing of precursors to secret the mature proteins (Cooper and Bussey, 1989). The toxin binds to a glucan receptor on the cell wall (Al-Aidroos and Bussey, 1978; Bussey, 1991) and to the sites on the membrane (Bussey et al., 1973a) of target yeast. Therefore, the susceptible yeast cells are killed in a two-step receptor-mediated manner.

It is well established that at high specific growth rates Sacch. cerevisiae exhibits a mixed metabolism, even under aerobic glucose-limited conditions. A limitation in respiratory capacity results to a phenomenon known as overflow metabolism or Crabtree effect and leads to the formation of byproducts (Vemuri et al., 2007). It has also been demonstrated that the ethanol overflow in Sacch. cerevisiae is related to a redox imbalance in the mitochondria (Hou et al., 2009; Hou et al., 2010). Deken (1966a) observed that under critical values, an exponentially growing yeast could proceed the degradation of carbohydrate through fermentation and respiration simultaneously. The regulation of the glycolytic enzymes cannot be extrapolated from one Sacch. cerevisiae strain to the other (Deken, 1966a; Hoek et al., 2000). With the exception of phosphofructokinase and pyruvate decarboxylase of an industrial strain, no clear correlation between the fermentative capacity and the glycolytic enzymes activities was observed (Hoek et al., 2000). Comparison between Crabtree-positive and Crabtree-negative strains revealed that the fermentative pathway was constitutive for the strain with strong Crabtree effect (Deken, 1966a). These observations showed that when the respiring cells of Sacch. cerevisiae switched to alcoholic fermentation pathway they could alter several other regulatory mechanisms not directly correlated with ethanol production. Brink et al. (2008) showed that shifts towards fermentative pathway provoke, as a matter of fact, great trasncriptional reprogramming with one third of all genes within the genome differentially transcribed. Similar behaviour has been observed with Escherichia coli. The transfer of these bacteria from aerobic to micro-anaerobic conditions changed the gene expression associated with the central metabolism, metal ion physiology and cell envelop stress (Partridge et al., 2007). In Sacch. cerevisiae, multiple pathways and mechanisms seemed to be involved in modulating the expression of hypoxic genes (Kwast et al., 1999).

The aim of this work was to study the effect of shift from fully aerobic to gradual anaerobic conditions upon functional killer protein production in batch culture by a Crabtree-positive killer yeast strain as well as its correlation with the products of anaerobic metabolism. A procedure for the determination of the minimum number of functional killer protein molecules present in the inhibition zone $\left(\mathrm{mnm}_{\mathrm{h}}\right)$ is also proposed.

\section{MATERIALS AND METHODS}

\section{Yeast strains}

The $\mathrm{K}^{+} \mathrm{R}^{+}$and $\mathrm{K}^{-} \mathrm{R}^{-}$yeast strains Saccharomyces cerevisiae Embrapa 1B/04 and Saccharomyces cerevisiae Embrapa 26B/04, respectively, were obtained from the culture collection of the Centro Nacional de Pesquisa de Uva e Vinho (CNPUVEMBRAPA, Bento Gonçalves, RS, Brasil). These strains were isolated from Vitis vinifera $\mathrm{L}$. Riesling Italico grape must as previously described by da Silva (1987) and defined, respectively, as killer and sensitive strains by da Silva (1996). The strains were maintained at $18^{\circ} \mathrm{C}$ on must/agar slants (MA) and sub-cultured every six months.

\section{Growth media and shift experiment}

The growth of Sacch. cerevisiae EMBRAPA$1 \mathrm{~B} / 04$ was carried out in a stirred-tank bioreactor (Biolafitte, Poissy, France) of 501 , equipped with temperature, $\mathrm{pH}$ control and internal pressure measurement. Agitation, aeration, temperature and internal pressure were fixed at $350 \mathrm{rpm}, 2 \mathrm{vvm}$ air, $25^{\circ} \mathrm{C}$ and 0.3 bar, respectively. The initial $\mathrm{pH}$ of the culture was 3.75 and it was not controlled. The M5 complex medium composition was as follows: 5\% Lorena grape must and 95\% FYE (fresh yeast extract). The FYE was prepared as described by da Silva and de Almeida (2006). The 16.41 complex medium were sterilised in situ at $121^{\circ} \mathrm{C}$ for $30 \mathrm{~min}$. The Lorena grape must had a concentration of reducing sugar of $195 \mathrm{~g} / \mathrm{l}$. The sugar concentration in the fermentation medium was $9.75 \mathrm{~g} / \mathrm{l}$. After a fast cooling, the bioreactor was inoculated with 3.61 exponential-phase $\mathrm{K}^{+} \mathrm{R}^{+}$yeast culture. The inoculum was grown in six Fernbach flasks 
containing $600 \mathrm{ml}$ of the medium described as above at $25^{\circ} \mathrm{C}$ on a rotary shaker (model G25 Incubator shaker; New Brunswick, Scientific Co. Inc., Edison N.J.) at $150 \mathrm{rpm}$. After eight hours of aerobic growth, the shift from aerobic to anaerobic conditions was gradually performed, switching off both the air sparging and the mechanical agitation system. Samples were collected and analysed every one hour over an eight hour period. Two samples were taken at 24 and $48 \mathrm{~h}$. The samples were centrifuged at $10,000 \mathrm{x} \mathrm{g}$ in a Sorval centrifuge (USA) for $15 \mathrm{~min}$. Aliquots of $5 \mathrm{ml}$ of supernatant were sterilised by filtration using 0.22 $\mu \mathrm{m}$ on sterile Millipore filters (MilliporeJBR610021, USA). The rest of the supernatant (195 ml) was used to determine the amount of residual sugar and metabolites.

\section{Flask cultures}

One set of three flasks containing $1640 \mathrm{ml}$ sterile M5 medium each was gassed with air (2 vvm air) without mechanical stirring. The other set of three flasks containing $1640 \mathrm{ml}$ sterile M5 medium each was sparged with sterile filtered $(0.22 \mu \mathrm{m}$ Millipore filters Millipore-JBR610021, USA) $\mathrm{N}_{2}$ for one minute (at a flow rate of $4-51 / \mathrm{min}$ ). A third set of three flasks containing $1640 \mathrm{ml}$ sterile M5 modified medium by the addition of $100 \mathrm{~g} / \mathrm{l}$ sucrose each was gassed with air (2 vvm air) without mechanical stirring. All the flasks were inoculated with $360 \mathrm{ml}$ of a cell suspension at $10^{7}$ cells of Sacch. cerevisiae EMBRAPA-1B/04/ml. The flasks were allowed to stand for $24 \mathrm{~h}$ at room temperature. Samples were collected and analysed every one hour over an eight hour period and over a period of $24 \mathrm{~h}$.

\section{Analysis of anaerobic metabolites}

The ethanol was distilled from $100 \mathrm{ml}$ of fermented medium and the distillate was filled up with distilled water to a volume of $100 \mathrm{ml}$. The total ethanol was then determined by measuring the density of the distillate with an Anton-Paar DMA58 densitometer. The temperature of the sample was controlled with a water bath (Haag-G, West Germany). The concentration of acetaldehyde was measured by capillary gas chromatography (Perkin Elmer AutoSystem XL), equipped with a flame-ionisation detector (FID), a capilar column $(0.25 \mathrm{~mm}$ i.d. by $50 \mathrm{~m} \mathrm{-}$ CPWAX57B), and a split/splitless injector. Splitless injections were made onto the column at $40^{\circ} \mathrm{C}$ (5-min hold) with oven programming from $40^{\circ} \mathrm{C}\left(2^{\circ} \mathrm{C} / \mathrm{min}\right)$ to $60^{\circ} \mathrm{C}(10 \mathrm{~min})$, then $\left(15^{\circ} \mathrm{C} / \mathrm{min}\right)$ to $200^{\circ} \mathrm{C}(18 \mathrm{~min})$. The 4-methyl-pentanol-2 was used as internal standard and the separation was performed under a constant flow of $1.8 \mathrm{ml} \mathrm{He} / \mathrm{min}$ at $30 \mathrm{psi}$ head pressure, $85.7 \mathrm{ml}$ sinthetic air/min and $53.1 \mathrm{H}_{2} \mathrm{ml} / \mathrm{min}$.

\section{Analysis of reducing sugar}

The reducing sugar and sucrose assays were done by reduction of Fehling alkaline cupric solutions as described by Ribéreau-Gayon et al. (1982). When sucrose was used, the samples were first hydrolysed using $1 \mathrm{ml} \mathrm{HCl}$.

\section{Measurement of growth}

The growth was measured by monitoring the changes in optical density (OD) of the culture at $600 \mathrm{~nm}$ with a Perkin-Elmer UV/visible spectrophotometer (Lambda Bio, Illinois, USA). Dilutions of culture were made in order to get an OD between 0.1 and 0.2. Total cell and budding cells numbers were determined microscopically (Universal III Microscope, Zeiss Germany) with a cell chamber (Neubauer Improved Superior, Germany), using the same dilutions for OD measurements. The specific growth rate $(\mu)$ was computed from the integration of $\mu \mathrm{x}=\mathrm{dx} / \mathrm{dt}$ in which $\mathrm{x}$ was the optical density at time $\mathrm{t}$.

\section{Killer toxin assay}

The unbuffered MA80-MB medium used to detect the functional killer activity of the cell-free supernatant had the following composition: $80 \%$ (v/v) Lorena grape must, 20\% (v/v) FYE, $0.003 \%$ $(\mathrm{w} / \mathrm{v})$ methylene blue and $1 \%(\mathrm{w} / \mathrm{v})$ Bacto agar, final $\mathrm{pH}$ 4.5. The agar was autoclaved separately to avoid the hydrolysis and, after being cooled to $45-50^{\circ} \mathrm{C}$, added just before pouring into a $9 \mathrm{~cm}$ diameter Petri dish. The presence of the functional killer toxin was determined by plating suspended sensitive cells of Sacch. cerevisiae Embrapa 26B/04 $\left(10^{7} \mathrm{cells} / \mathrm{ml}\right)$ as a lawn onto MA80-MB medium. Aliquots of $30 \mu \mathrm{l}$ of sterile cell-free supernatant were pipetted into a $0.5 \mathrm{~cm}$ well punched in the seed plate (Al-Aidroos and Bussey, 1978). The inoculated plates were transferred to Lab-Line Imperial II Radiant Incubator (Illinois, USA) at $25^{\circ} \mathrm{C}$ for $48-72 \mathrm{~h}$. If the well was surrounded by a clear zone of inhibition fringed with blue colour, the killer toxin was designated as functional. 


\section{Statistical analysis}

The regression analysis was performed by using $\mathrm{R}$ Program for Debian GNU/Linux (Venables, 2004; Logan, 2005); R version 2.7.1 (2008-06-23).

\section{RESULTS AND DISCUSSION}

\section{Estimation of minimum number of killer molecules}

It was observed that the killer toxin required at least two steps involving a cell wall receptor and the plasma membrane. The toxin initially bound to a cell wall receptor which contained a (1-6)- $\beta$-Dglucan (Al-Aidroos and Bussey, 1978; Hutchins and Bussey, 1983). Although $1.1 \times 10^{7}$ receptor per cell seemed to be necessary for toxin action, only $2.8 \times 10^{4}$ toxin molecules proved to be enough to kill one sensitive cell of Sacch. cerevisiae S14a (Bussey et al., 1979; Bussey, 1981; Tipper and Bostian, 1984). The calculation based on the latter value to estimate the minimum number of killer toxin molecules on the surface of the solid culture media that had killed a defined number of sensitive cells is given by the equation 1.

The constant $k_{2}$ represented the number of cells that were removed with punched agar cylinder at the time of making the wells (equation 2). The $\mathrm{mnm}_{\mathrm{h}}$ was the minimum number of molecules present in the inhibition zone; $\mathrm{k}_{1}$ was a constant equal to $2.8 \times 10^{4} ; \mathrm{D}_{\mathrm{h}}$ was the diameter of the inhibition zone; $D_{p}$ was the diameter of the Petri dish $(9 \mathrm{~cm})$; nc corresponded to the number of sensitive cells expressed in cells $/ \mathrm{ml}\left(10^{7}\right.$ cells $\left./ \mathrm{ml}\right)$ in stock suspension; $\mathrm{v}$ was the volume of the latter used for inoculation $(0.1 \mathrm{ml})$. The $\mathrm{D}_{\mathrm{w}}$ was the diameter of the punched agar cylinder. The minimum number of killer molecules for the diameter of $1.2 \mathrm{~cm}$ long (Fig. 1) based on the equation 1 was $4.11 \times 10^{8}$ molecules.

$$
\begin{aligned}
& n m m_{h}=K_{1} \times\left\{\left[\left(\frac{D_{h}}{D_{p}}\right)^{2} \times(n c \times v)-K_{2}\right]\right\} \\
& K_{2}=\left(\frac{D_{w}}{D_{p}}\right)^{2} \times(n c \times v)
\end{aligned}
$$

\section{Shift from aerobiosis to anaerobiosis}

In bioreactor, the functional killer protein could not be detected during the aerobic growth (Fig. 1) in M5 medium with $10 \mathrm{~g} / \mathrm{l}$ reducing sugar. During the aerobic phase, the yeast presented an exponential growth between two and seven hours, according to the equation 3 . It should be noted, from equation 3 , that the maximum specific growth rate ( $\mu$ max $)$ of this yeast was $0.37 \mathrm{~h}^{-1}$ with doubling time $\left(\mathrm{t}_{\mathrm{d}}\right)$ of approximately $1.87 \mathrm{~h}$ (equation 5). The number of generations between 2 and $9 \mathrm{~h}$ of aerobic growth was 2.93 (equation 6). The killer activity was only observed $16 \mathrm{~h}$ after the shift from aerobic to gradual anaerobic conditions. The diameter of the halo around the wells formed at $16 \mathrm{~h}$ in anaerobiosis was $1.2 \mathrm{~cm}$.

$$
\begin{aligned}
& D O=0.0277 e^{0.3723 t} \\
& r^{2}=0.9967 \\
& t_{d}=\frac{\ln 2}{0.37}=1.87 \mathrm{~h} \\
& g n=\frac{1}{\log 2} \log \frac{0.4379}{0.0573}=2.93
\end{aligned}
$$

The minimum number of functional killer toxin molecules present in the inhibition zones was 4.11 $\mathrm{x} 10^{8}$. In aerobic conditions, the results obtained in flask culture and in bioreactor were not the same. In bioreactor (Fig. 1), as soon as the aeration and agitation systems were switched off, the functional killer protein started being produced. In flask, no detectable killer protein was formed in seven hours of aerobic growth (Fig. 2). However, this protein was produced over the course of aerobic phase since $1.35 \times 10^{8}$ molecules could be observed in eight hours of aerobic growth (Fig. 3). In anaerobiosis, the minimum number of functional killer toxin molecules present in the inhibition zones was the same as in bioreactor $\left(4.11 \times 10^{8}\right)$. The difference between the results obtained in the bioreactor and those observed in the flasks in aerobiosis could be due to the aeration inefficiency of unbaffled aerated flasks, resulting in partial oxygen unavailability. Therefore, there was some evidence to support that the aeration or a related mechanism was involved in the regulation of killer protein synthesis. 


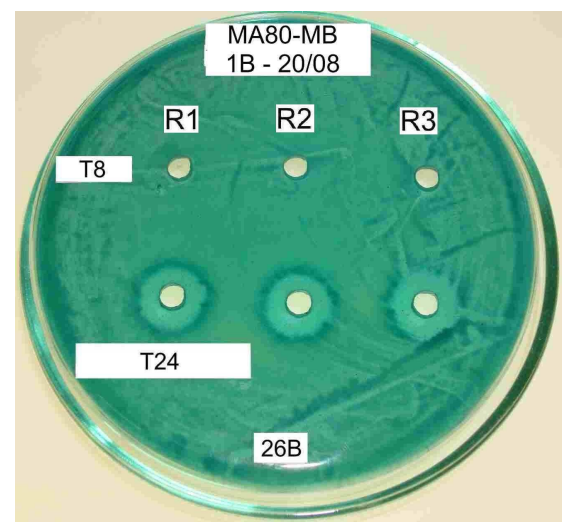

Figure 1 - Killer toxin produced by the killer strain Sacch. cerevisiae Embrapa 1B/04 - inactivity after $8 \mathrm{~h}$ (T8) in aerobiosis and activity after $16 \mathrm{~h}$ period $(1.2 \mathrm{~cm})$ in anaerobiosis (T24); Sensitive strain: Sacch. cerevisiae Embrapa 26B/04; Detection medium: MA80MB; Expression medium: M5. R: repetitions.

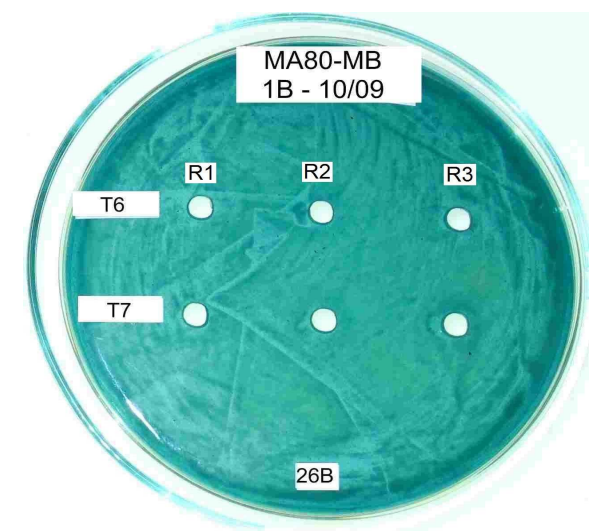

Figure 2 - Killer toxin produced by the killer strain Sacch. cerevisiae Embrapa 1B/04 - inactivity before eight hour period in aerobiosis (after six hour period: T6 and after seven hour period: T7); Sensitive strain: Sacch. cerevisiae Embrapa 26B/04; Detection medium: MA80-MB; Expression medium: M5. R: repetitions.

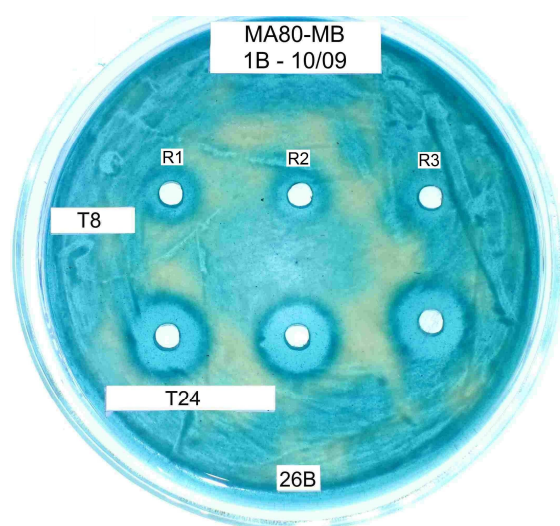

Figure 3 - Killer toxin produced by the killer strain Sacch. cerevisiae Embrapa 1B/04 - weak activity after eight hour period (T8) in aerobiosis $(0.8 \mathrm{~cm})$ and strong activity after 16 $\mathrm{h}$ period $(1.2 \mathrm{~cm})$ in anaerobiosis (T24); Sensitive strain: Sacch. cerevisiae Embrapa 26B/04; Detection medium: MA80-MB; Expression medium: M5. R: repetitions. 
As expected, during the aerobic growth in the bioreactor, no ethanol was found in the supernatant of aerobic cultures as well as killer protein (Fig. 4). There seemed to be an incompatibility between the aerobic metabolism and the functional killer proteins synthesis. To establish a link between the aerobic and anaerobic processes, quantitative analysis of acetaldehyde and ethanol were performed. Although these two compounds are intimately related to glycolysis, the synthesis of ethanol, but not acetaldehyde, depends upon NADH oxidation. If the pyruvic acid is driven toward Krebs cycle, as it should occur in aerobiosis, the concentration of acetaldehyde and ethanol should be, if not null, negligible. In fact, the concentration of ethanol was null. Interestingly, and contrary to the case for ethanol, acetaldehyde increased continuously with time under aerobic conditions and decreased as soon as the anaerobiosis started (Fig. 4). These results showed that the key enzyme of alcoholic fermentation, pyruvate decarboxylase (PDC), was active even under aerobiosis and without ethanol formation. Postma et al. (1989) observed that the pyruvate decarboxylase probably was operative under the conditions in which alcoholic fermentation was absent. The acetaldehyde could be then oxidised by acetaldehyde dehydrogenase and acetyl-CoA synthetase to form acetyl-CoA, which in turn, would be further oxidised in the mitochondria. The acetaldehyde built up (Fig. 4) probably due to low activity of the acetyl-CoA synthetase.

The evolution of acetaldehyde during the aerobic phase is described by the following equation:

$$
\begin{aligned}
& \text { aceth }=-0.2011 x^{2}+8.2092 x+49.3111 \\
& r^{2}=0.9038
\end{aligned}
$$

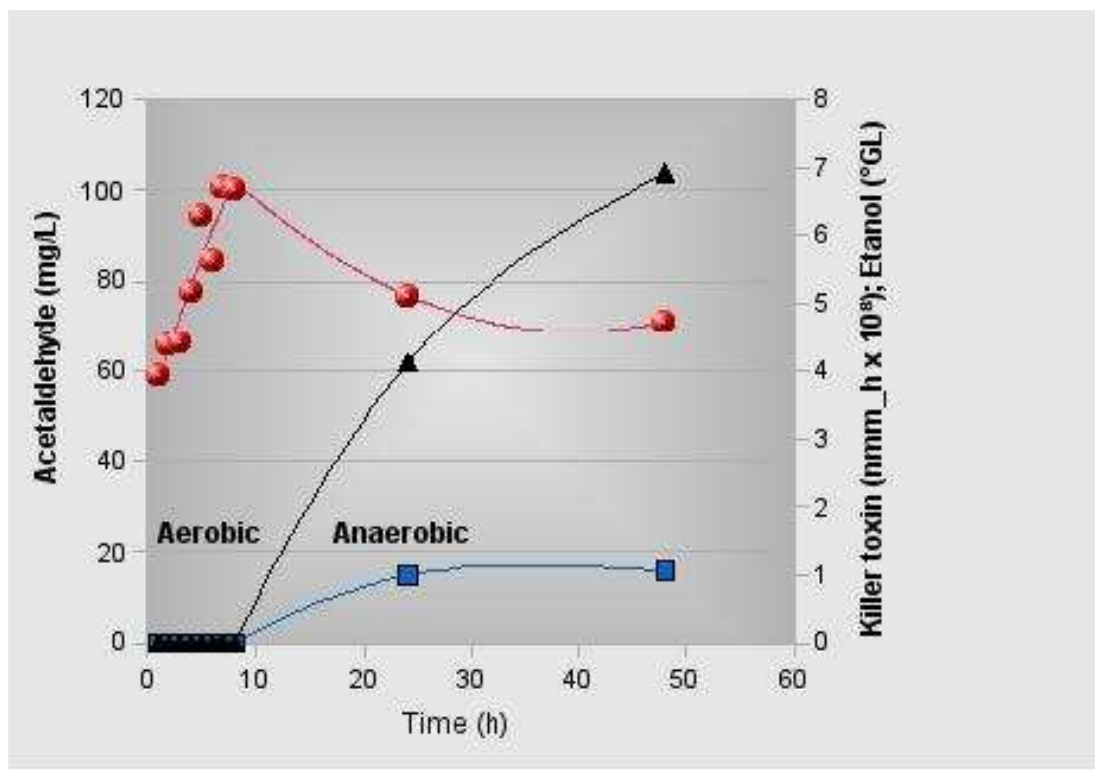

Figure 4 - Levels of ethanol $(\square)$, acetaldehyde ( $($ ) and minimum number of molecules (mnmh) ( $\Delta$ ) of functional killer toxin, calculated by Equation 1, in supernatant of Sacch. cerevisiae Embrapa 1B/04 cultures grown in M5 medium and in bioreactor. During the first 8 hour period, the growth was maintained in aerobic conditions. After this period the conditions were gradually shifted to anaerobiosis.

The hypothesis that mechanical stirring could provoke the killer protein inactivation was not supported because the cell-free supernatant of the cells grown in aerated 2.8-litre. Fernbach flasks without mechanical stirring did not present functional killer protein before eight hours of aerobic growth (Fig. 2). The agitation obtained by air sparging did not inhibit the production of the killer protein, since the presence of such a protein was detected after eight hours of aerobic growth. 
The protein was earlier detected in sterile cell-free supernatant of cells grown without aeration (Fig. 5 and 6). The diameters of the halo around the wells formed over $6,7,8$ and $24 \mathrm{~h}$ period in anaerobiosis were, respectively, 0.93, 1.1, 1.0 and $1.2 \mathrm{~cm}$ long, which corresponded to a minimum number of functional killer toxin.

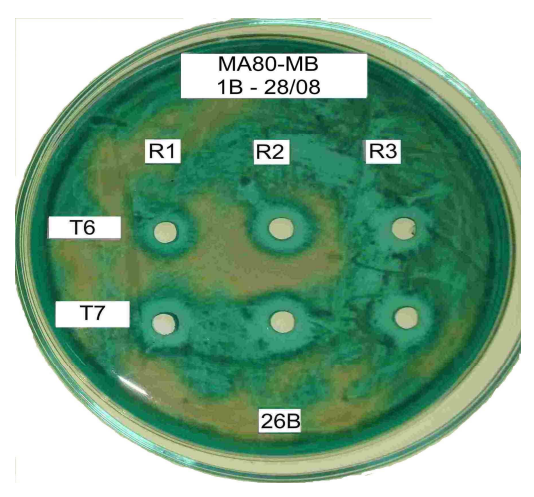

Figure 5 - Presence of functional killer protein in supernatant of Sacch. cerevisiae Embrapa 1B/04 cultures grown in M5 (expression medium) for six $(0.93 \mathrm{~cm})(\mathrm{T} 6)$ and seven $(1.1 \mathrm{~cm})$ hours (T7), in anaerobiosis and in flask culture; Sensitive strain: Sacch. cerevisiae Embrapa 26B/04; Detection medium: MA80-MB; R: repetitions.

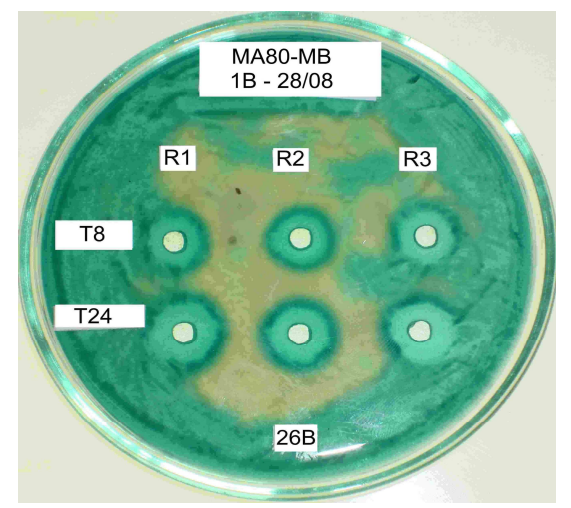

Figure 6 - Presence of functional killer protein in supernatant of Sacch cerevisiae Embrapa 1B/04 cultures grown in M5 (expression medium) for eight $(1.0 \mathrm{~cm})(\mathrm{T} 8)$ and $24(1.2 \mathrm{~cm}) \mathrm{h}$ period (T24), in anaerobiosis and in flask culture; Sensitive strain: Sacch. cerevisiae Embrapa 26B/04; Detection medium: MA80-MB; R: repetitions.

As in both aerobic and anaerobic conditions the mechanical stirring system was absent, there was strong evidence for the involvement of the anaerobic metabolism in regulating the synthesis of functional killer protein. Hence, the results did not support the hypothesis of protein inactivation by the mechanical stirring used in the bioreactor culture. Figure 4 showed that the aerobic conditions did not repress the production of acetaldehyde (aceth) but inhibited ethanol and functional killer protein synthesis. These findings suggested that the last two processes were related.
The expression of some proteins of both eucaryotes and prokaryotes is significantly modified by the aerobiosis or anaerobiosis. In yeasts, the signal involved in the induction of certain genes and produced by respiratory chain can be generated in anaerobic conditions (Kwast et al., 1999). A peptidase (PepR) of Lactobacillus sakei was expressed as a single 1.27-kb transcript induced under anaerobiosis. These proteins could be assigned to respiratory or carbon flux functions, and proteins subjected to catabolite repression have been shown to be also regulated by growth 
under anaerobiosis (Champomier-Vergs et al., 1996). In Neisseria gonorrhoeae, a shift from aerobiosis to anaerobiosis induced the synthesis of outer membrane proteins (Clark et al., 1987) and in Bacillus subtilis, there was the induction of various systems for the utilisation of alternative carbon sources (Marino et al., 2000).

\section{Production of killer protein in aerobic conditions}

It became clear that the presence of air was, to some extent, the cause of the inhibition of functional killer protein production. The metabolic behaviour that governs the killer toxin synthesis seems to be of the same nature as the ones observed for ethanol production. If this was true, the Pasteur effect could be extended to killer protein synthesis. In the same way, a positive Crabtree effect killer yeast strain can form the functional killer toxin if the sugar concentration surpasses a critical threshold value because, in such an yeast, alcoholic fermentation may set in even under aerobic conditions. To test the involvement of Crabtree effect in killer toxin production, the Crabtree-positive strain Sacch. cerevisiae Embrapa 1B/04 was allowed to grow in the flasks containing $1640 \mathrm{ml}$ sterile M5 medium with $100 \mathrm{~g} / \mathrm{l}$ sucrose. The growth assay was performed under the aerobic conditions and without mechanical stirring.

The presence of the functional killer protein could be clearly defined during the entire aerobic process (Fig. 7 and 8). The minimum number of killer molecules $\left(\mathrm{mnm}_{\mathrm{h}}\right)$ produced increased with the time, following the cell yeast growth (Fig. 9). In the conditions of high sugar concentration, even under aerobiosis, the metabolism of the strain was driven toward the growth, ethanol and killer protein production. The ethanol concentration and the minimum number of killer molecules measured in the cell culture supernatant at $24 \mathrm{~h}$ was $3.26^{\circ} \mathrm{GL}$ and $9.92 \times 10^{8}$, respectively. According to Bai et al. (2008), ethanol is a typical primary metabolite whose production is tightly coupled with the growth of yeast cells. The equation 9 defines the growth of this strain in high sugar concentration and in aerobiosis during the seven hours of exponential phase. This showed that the maximum specific growth rate (umax) of this microorganism grown in aerated unbaffled Fernbach flask with high sugar concentration was $0.16 \mathrm{~h}^{-1}$ with a doubling time of approximately 4.3 hours (equation 11). The number of generations between 0 and $8 \mathrm{~h}$ of growth was 1.98 (equation 12).

$$
\begin{aligned}
& x=1.305 e^{0,16 t} \\
& r^{2}=0.9541 \\
& t_{d}=\frac{\ln 2}{0.16}=4.3 \mathrm{~h} \\
& g n=\frac{1}{\log 2} \log \frac{4.6509}{1.1762}=1.98
\end{aligned}
$$

The relationship between the yeast growth (x) and the minimum number of killer molecules $\left(\mathrm{mnm}_{\mathrm{h}}\right)$ during the aerobic process was obtained by the linearised potential equation (equation 13), where $\mathrm{x}$ was the optical density.

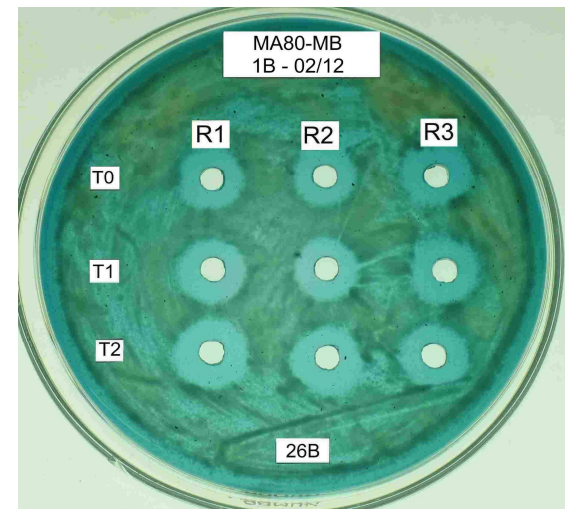

Figure 7 - Presence of functional killer protein during $0(1.13 \mathrm{~cm})(\mathrm{T} 0), 1(1.17 \mathrm{~cm})(\mathrm{T} 1)$ and 2 $(1.27 \mathrm{~cm})(\mathrm{T} 2)$ hour period in supernatant of a culture of Sacch. cerevisiae Embrapa 1B/04 grown aerobically in M5 expression medium supplemented with $100 \mathrm{~g} / 1$ sucrose in flask culture; Sensitive strain: Sacch. cerevisiae Embrapa 26B/04; Detection medium: MA80-MB. R: repetitions. 


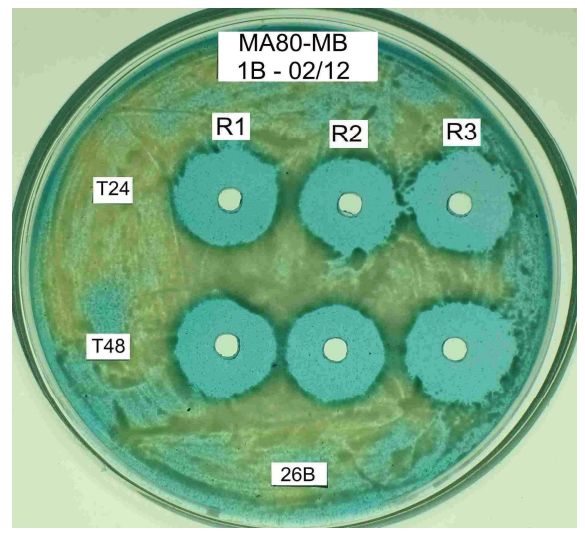

Figure 8 - Presence of functional killer protein during $24(1.77 \mathrm{~cm})(\mathrm{T} 24)$ and $48(1.83 \mathrm{~cm}) \mathrm{h}$ period (T48) in supernatant of a culture of Sacch. cerevisiae Embrapa 1B/04 grown aerobically in M5 expression medium supplemented with $100 \mathrm{~g} / \mathrm{l}$ sucrose in flask culture; Sensitive strain: Sacch. cerevisiae Embrapa 26B/04; Detection medium: MA80-MB. R: repetitions.

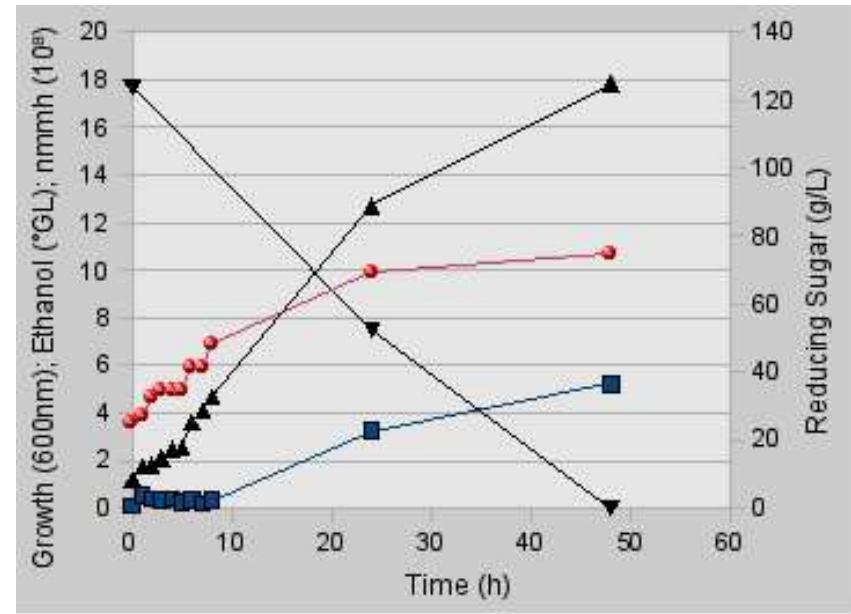

Figure 9 - Aerobic growth of Sacch. cerevisiae Embrapa 1B/04 ( $\boldsymbol{\square})$, ethanol production ( $\boldsymbol{\Delta}$ ), minimum number of functional killer molecules (mnmh) ( O ) and residual reducing sugar $(\boldsymbol{\nabla})$; M5 expression medium supplemented with $100 \mathrm{~g} / \mathrm{l}$ sucrose.

The numeric values of this relationship can be seen from equation 14 . The minimum number of killer molecules increased with the yeast growth at a rate of a power of 0.41 per arbitrary optical density unit. The relationship found for the growth and the killer protein production during the entire process was observed neither for ethanol production and growth nor for killer protein formation and ethanol production.

$$
\begin{aligned}
& \ln \left(\text { mnm }_{h}\right)=\ln \left(m_{n m}\right)+k \ln (x) \\
& m n m_{h}=3.4168 x^{0.4128} \\
& r^{2}=0.9724
\end{aligned}
$$

The relationship between the minimum number of killer molecules $\left(\mathrm{mnm}_{\mathrm{h}}\right)$ and ethanol (etoh) production followed a logarithmic equation over a period of $41 \mathrm{~h}$ (from 7 to $48 \mathrm{~h}$ ) (Equation 16). During this same period, the relationship between the growth $(\mathrm{x})$ and ethanol was linear (Equation 18).

$$
\begin{aligned}
& \text { mnm }_{h}=8.3229+1,4195 \ln (\text { etoh }) \\
& r^{2}=0.9967 \\
& \text { Etoh }=-1.3497+0.3665 x \\
& r^{2}=0.9997
\end{aligned}
$$


The concomitant production of ethanol and killer toxin in the presence or in absence of air may mean that the synthesis of these two metabolic products is governed by related mechanisms. The results showed that the killer protein synthesis system in Sacch. cerevisiae could be intimately coupled to the ethanol production process and that the aerobiosis itself did not interfere with its biological activity or with its production only if the sugar concentration surpassed the critical threshold value. It is well known that the formation of ethanol in aerobic cultures is a metabolic characteristic of Sacch. cerevisiae growing in the presence of excess glucose. This phenomenon is known as the Crabtree effect (Romo et al., 1965; Deken, 1966a; Deken, 1966b; Hommes, 1966; Postma et al., 1989; van Urk et al., 1989a, van Urk et al., 1990; Lu et al., 2008) and is not displayed by all yeasts (Reynders et al., 1997). It was clear that Sacch. cerevisiae Embrapa 1B/04 was a Crabtree-positive strain. Postma et al. (1989) observed that glucose was completely respired when Sacch. cerevisiae CBS 8066 was grown in dilution rate below $0.30 \mathrm{~h}^{-1}$ and that a further increase in the dilution rate resulted in aerobic alcoholic fermentation in addition to respiration. According to these authors, the occurrence of alcoholic fermentation was not primarily due to a limited respiratory capacity but was due to an uncoupling effect on its respiration caused by the organic acids produced.

It would be important to note that this strain (Sacch. cerevisiae Embrapa 1B/04) also presented sensitivity to killer protein obtained from the strain Sacch. cerevisiae Embrapa 91B/04 (da Silva, 1999b). This mean that this strain showed a killer/sensitive phenotype. This phenomenon did not seem to be rare. Sangorrín et al. (2001) have also observed that all wild killer strains isolated from Merlot and Malbec musts of Northwestern Patagonia (Argentina) were sensitive to some killer reference toxins. The same behaviour was also found by Sangorrín et al. (2007) for all killer yeasts isolated from the fermentation vat surfaces. The yeast sensitivity to killer toxin (VaughanMartini et al., 1996; Sangorrín et al., 2002) and killer ability seemed to be a strain-related characteristics since some killer yeast strains were not able to kill the Sacch. cerevisiae Embrapa 1B/04 (da Silva, 1999b).
The results suggested that the functional killer protein expression depended upon the stress imposed to cells by the culture medium composition or by culture conditions. Breierová (1997) observed that yeasts produced cryoprotectant glycoproteins under induced stress conditions. The anaerobiosis and the presence of high level of sugar concentration stimulate the sugar consumption rate. This stimulation is provoked by stress conditions and also seems to have influence upon the production of killer toxins. The increase in osmotic pressure can alter not only the level of cellular products but also their rates of synthesis. It was observed that 18 proteins of Sacch. cerevisiae had more than eight-fold increases in their synthesis rates when the yeast was transferred to $0.7 \mathrm{M} \mathrm{NaCl}$ medium. These proteins seemed to be gene products that responded to dehydration (Blomberg, 1995). There are specific genes, kex1 and kex2 (for killing expression), that are necessary for a strain to secrete an active toxin (Wickner and Leibowitz, 1976). It is possible that the synthesis of the products of these genes was increased not only by the osmotic pressure provoked by the high levels of sugar of the grape must but also by anaerobic conditions.

\section{ACKNOWLEDGEMENT}

The authors thank the CNPq and Capes for financial support.

\section{REFERENCES}

Al-Aidroos, K., Bussey, H. (1978), Chromosomal mutants of Saccharomyces cerevisiae affecting the cell wall binding site for killer factor. Can. J. Microbiol., 24, 228237.

Bai, F.W., Anderson, W.A., Moo-Young, M. (2008), Ethanol fermentation technologies from sugar and starch feedstocks. Biotechnol. Adv., 26, 89-105.

Bajaj, B. K., Sharma, S. (2010) Construction of killer industrial yeast Saccharomyces cerevisiae $\{\mathrm{HAU}\}-1$ and its fermentation performance. Braz. J. Microbiol., 41, 477-485.

Blomberg, A. (1995), Global changes in protein synthesis during adaptation of the yeast Saccharomyces cerevisiae to $0.7 \mathrm{M} \mathrm{NaCl}$. J Bacteriol., 177, 3563-3572. 
Boone, C., Bussey, H., Greene, D., Thomas, D. Y., Vernet, T. (1986), Yeast killer toxin: site-directed mutations implicate the precursor protein as the immunity component. Cell, 46, 105-113.

Bostian, K. A., Elliott, Q., Bussey, H., Burn, V., Smith, A., Tipper, D. J. (1984), Sequence of the preprotoxin dsRNA gene of type I killer yeast: multiple processing events produce a two-component toxin. Cell, 36, 741751.

Breierová, E. (1997), Yeast exoglycoproteins produced under $\mathrm{NaCl}$-stress conditions as efficient cryoprotective agents. Lett. Appl. Microbiol., 25, 254-256.

Bussey, H., Sherman, D., Somers, J. M. (1973), Action of yeast killer factor: a resistant mutant with sensitive spheroplasts. J. Bacteriol., 113, 1193-1197.

Bussey, H., Skipper, N. (1975), Membrane-mediated killing of Saccharomyces cerevisiae by glycoproteins from Torulopsis glabrata. J. Bacteriol., 124, 476-483.

Bussey, H., Saville, D., Hutchins, K., Palfree, R. G. (1979), Binding of yeast killer toxin to a cell wall receptor on sensitive Saccharomyces cerevisiae. J. Bacteriol., 140, 888-892.

Bussey, H. (1981), Physiology of killer factor in yeast. Adv. Microb. Physiol., 22, 93-122.

Bussey, H. (1991), K1 killer toxin, a pore-forming protein from yeast. Mol. Microbiol., 5, 2339-2343.

Cabral, A. S., Carvalho, P. M. B.; Pinotti, T., Hagler, A. N., Mendonça-Hagler, C. S., Macrae, A. (2008), Killer yeasts inhibit the growth of the phytopathogen Moniliophthora perniciosa, the causal agent of witches' broom disease. Braz. J. Microbiol., 40, 108-110.

Cansado, J., Velázquez, J. B., Sieiro, C., Gacto, M., Villa, T. G. (1999), Presence of non-suppressive, M2-related dsRNAs molecules in Saccharomyces cerevisiae strains isolated from spontaneous fermentations. FEMS Microbiol. Lett., 181, 211-215.

Ceccato-Antonini, S. R., Tosta, C. D., Silva, A. C.da, (2004), Determination of yeast killer activity in fermenting sugarcane juice using selected ethanolmaking strains. Braz. Arch. Biol. Technol., 47, 13-23.

Champomier-Vergs, M. C., Stintzi, A., Meyer, J. M. (1996), Acquisition of iron by the non-siderophoreproducing Pseudomonas fragi. Microbiology, 142, 1191-1199.

Clark, V. L., Campbell, L. A., Palermo, D. A., Evans, T. M., Klimpel, K. W. (1987), Induction and repression of outer membrane proteins by anaerobic growth of Neisseria gonorrhoeae. Infect Immun., 55, 1359-1364.

Cooper, A., Bussey, H. (1989), Characterization of the yeast kex1 gene product: a carboxypeptidase involved in processing secreted precursor proteins. Mol. Cell Biol., 9, 2706-2714.

Cooper, A., Bussey, H. (1992), Yeast kex1p is a golgiassociated membrane protein: deletions in a cytoplasmic targeting domain result in mislocalization to the vacuolar membrane. J. Cell Biol., 119, 1459-1468.

da Silva, G. A. (1996), The occurrence of killer, sensitive, and neutral yeasts in Brazilian Riesling Italico grape must and the effect of neutral strains on killing behaviour. Appl. Microbiol. Biotechnol., 46, 112-121. da Silva, G. A. (1999a), Comportamento de leveduras isoladas no Vale dos Vinhedos em Bento Gonçalves, $\mathrm{RS}$, com relação à atividade killer. In-Anais do IX Congresso Brasileiro de Viticultura e Enologia, ed. J. Tonietto, C. C. Guerra, Bento Gonçalves. Embrapa Uva e Vinho, p. 170.

da Silva, G. A. (1999b), Evidência de uma linhagem de levedura com característica killer, neutra e sensível. InAnais do IX Congresso Brasileiro de Viticultura $e$ Enologia, Ed. J. Tonietto, C. C. Guerra, Bento Gonçalves. Embrapa Uva e Vinho, p. 169.

da Silva, G. A., de Almeida, E. A. (2006), Production of yellow-green fluorescent pigment by Pseudomonas fluorescens. Braz. Arch. Biol. Technol., 49, 411-419.

da Silva, M. A. A. A., da Silva, G. A. (1987), Leveduras nacionais selecionadas para a elaboração de vinho. Technical report, Embrapa, CNPUV, Circular Técnica Bento Gonçalves, pp. 5-9.

Deken, R. H. D. (1966a), Crabtree effect: a regulatory system in yeast. J. Gen. Microbiol., 44, 149-156.

Deken, R. H. D. (1966b), The Crabtree effects and its relation to the petite mutation. J. Gen. Microbiol., 44, 157-165.

Eisfeld, K., Riffer, F., Mentges, J., Schmitt, M. J. (2000), Endocytotic uptake and retrograde transport of a virally encoded killer toxin in yeast. Mol. Microbiol., 37, 926940.

Gutiérrez, A. R., Epifanio, S., Garijo, P., López, R.., Santamaría, P. (2001), Killer yeasts: incidence in the ecology of spontaneous fermentation. Am. J. Enol. Vitic., 52, 352-356.

Heard, G. M., Fleet, G. H. (1987), Occurrence and growth of killer yeasts during wine fermentation. Appl. Environ. Microbiol., 53, 2171-2174.

Hidalgo, P., Flores, M. (1994), Occurrence of the killer character in yeasts associated with Spanish wine production. Food Microbiol., 11, 161-167.

Hoek, P. V., Dijken, J. P. V., Pronk, J. T. (2000), Regulation of fermentative capacity and levels of glycolytic enzymes in chemostat cultures of Saccharomyces cerevisiae. Enzyme Microb. Technol., 26, 724-736.

Hommes, F. A. (1966), Mechanism of the Crabtree effect in yeast grown with different glucose concentrations. Arch. Biochem. Biophys., 113, 324-330.

Hou, J., Lages, N.F., Oldiges, M., Vemuri, G.M. (2009), Metabolic impact of redox cofactor perturbations in Saccharomyces cerevisiae. Metab. Eng., 11, 253-261.

Hou, J., Scalcinati, G., Oldiges, M., Vemuri, G.M. (2010), Metabolic impact of incresead NADH availability in Saccharomyces cerevisiae. Appl. Environ. Microbiol., 76, 851-859.

Hutchins, K., Bussey, H. (1983), Cell wall receptor for yeast killer toxin: involvement of (1 leads to 6)- beta-dglucan. J. Bacteriol., 154, 161-169.

Kapsopoulou, K., Barouti, E., Makrioniti, A., Kostaki, K. (2008), Occurrence of Saccharomyces cerevisiae killer yeasts in wine-producing areas of Greece. World $J$. Microbiol. Biotechnol., 24, 1967-1971. 
Kwast, K. E., Burke, P. V., Staahl, B. T., Poyton, R. O. (1999), Oxygen sensing in yeast: evidence for the involvement of the respiratory chain in regulating the transcription of a subset of hypoxic genes. Proc. Natl. Acad. Sci. USA, 96, 5446-5451.

Logan, M. (2005), R and S-PLUS: Basic instructions. Monash University, School of Biological Sciences.

Lu, M., Ji, 1., Liu, y., Zhou, P., Yu, L. (2008), Kinetic model for optimal feeding strategy in astaxanthin production by Xanthophyllomyces dendrorhous. Sheng Wu Gong Cheng Xue Bao, 24, 1937-1942.

Marino, M., Hoffmann, T., Schmid, R., Mbitz, H., Jahn, D. (2000), Changes in protein synthesis during the adaptation of Bacillus subtilis to anaerobic growth conditions. Microbiology, 146, 97-105.

Musmanno, R.A., Di Maggio, T., Coratza, G. (1999), Studies on strong and weak killer phenotypes of wine yeasts: production, activity of toxin in must, and its effect in mixed culture fermentation. J. Appl. Microbiol., 87, 932-938.

Partridge, J. D., Sanguinetti, G., Dibden, D. P., Roberts, R. E., Poole, R. K., Green, J. (2007), Transition of Escherichia coli from aerobic to micro-aerobic conditions involves fast and slow reacting regulatory components. J. Biol. Chem., 282, 11230-11237.

Postma, E., Verduyn, C., Scheffers, W. A., Dijken, J. P. V. (1989), Enzymic analysis of the Crabtree effect in glucose-limited chemostat cultures of Saccharomyces cerevisiae. Appl. Environ. Microbiol., 55, 468-477.

Reynders, M., Rawlings, D., Harrison, S. (1997), Demonstration of the Crabtree effect in Phaffia rhodozyma during continuous and fed-batch cultivation. Biotechnol. Lett., 19, 549-552.

Ribéreau-Gayon, J., Peynaud, E., Sudraud, P., RibéreauGayon, P. (1982), Traité d'Enologie. Siences et techniques du vin. Analyse et contrôle des vins, volume 1. Dunod, Paris.

Romo, E., de Prada, J. V., Herreros, B. (1965), Crabtree effect in yeast homogenates. Rev. Esp. Fisiol., 21, 173178.

Sangorrín, M. P., Zajonskovsky, I. E., Lopes, C. A., Rodríguez, M. E., de van Broock, M. R. G., Caballero, A. C. (2001), Killer behaviour in wild wine yeasts associated with Merlot and Malbec type musts spontaneously fermented from northwestern Patagonia (Argentina). J. Basic Microbiol., 41, 105-113.

Sangorrín, M. P., Zajonskovsky, I., van Broock, M., Caballero, A. (2002), The use of killer biotyping in an ecological survey of yeast in an old patagonian winery. World J. Microbiol. Biotechnol., 18, 115-120.

Sangorrín, M. P., Lopes, C. A., Giraudo, M. R., Caballero, A. C. (2007), Diversity and killer behaviour of indigenous yeasts isolated from the fermentation vat surfaces in four Patagonian wineries. Int. J. Food Microbiol., 119, 351-357.
Schmitt, M. J., Klavehn, P., Wang, J., Schnig, I., Tipper, D. J. (1996), Cell cycle studies on the mode of action of yeast k28 killer toxin. Microbiology, 142, 2655-2662.

Tipper, D. J., Bostian, K. A. (1984), Double-stranded ribonucleic acid killer systems in yeasts. Microbiol. Rev., 48, 25-156.

Vagnoli, P., Musmanno, R. A., Cresti, S., Di Maggio, T., Coratza, G. (1993), Occurrence of killer yeasts in spontaneous wine fermentations from the Tuscany Region of Italy. Appl. Environ. Microbiol., 59, 40374043.

Van den Brink, J., Daran-Lapujade, P., Pronk, J. T., de Winde, J. H. (2008), New insights into the Saccharomyces cerevisiae fermentation switch: dynamic transcriptional response to anaerobicity and glucoseexcess. BMC Genomics, 9, 100.

van Urk, H., Postma, E., Scheffers, W. A., van Dijken, J. P. (1989), Glucose transport in Crabtree-positive and Crbtree-negative yeasts. J. Gen. Microbiol., 135, 23992406.

van Urk, H., Voll, W. S. L., Scheffers, W. A., Dijken, J. P. V. (1990), Transient-state analysis of metabolic fluxes in Crabtree-positive and Crabtree-negative yeasts. Appl. Environ. Microbiol., 56, 281-287.

Vaughan-Martini, A., Cardinali, G., Martini, A. (1996), Differential killer sensitivity as a tool for fingerprinting wine-yeast strains of Saccharomyces cerevisiae. J. Industrial Microbiol. Biotechnol., 17, 124-127.

Vazquez, F., Toro, M. E. (1994), Occurrence of killer yeasts in Argentine wineries. World J. Microbiol. Biotechnol., 10, 358-359.

Vemuri, G.N., Eiteman, M.A., McEwen, J.E., Olsson, L., Nielsen, J. (2207), Increasing NADH oxidation reduces overflow metabolism in Saccharomyces cerevisiae. Proc. Natl. Acad. Sci. USA, 104, 2402-2407.

Venables, W. N., Smith, D. M., the R Development Core Team (2004), An introduction to R. The R Development Core Team, 2.0.1 edition. p. 1-90.

Wickner, R. B., Leibowitz, M. J. (1976), Two chromosomal genes required for killing expression in killer strains of Saccharomyces cerevisiae. Genetics, $\mathbf{8 2}$, 429-442.

Yap, N. A., de Barros Lopes, M., Langridge, P., Henschke, P. A. (2000), The incidence of killer activity of nonSaccharomyces yeasts towards indigenous yeast species of grape must: potential application in wine fermentation. J. Appl. Microbiol., 89, 381-389.

Zarowska, B., Wojtatowicz, M., Polomska, X., Juszczyk, P., Chrzanowska, J. (2004), Factors affecting killer activity of some yeast species occurring in Rokpol cheese. Folia Microbiol., 49, 713-717.

Received: October 20, 2009; Revised: July 01, 2010; Accepted: February 28, 2011 